\title{
Effect of cooperative learning strategy on students' retention in circle geometry in secondary schools in Benue State, Nigeria
}

\author{
Chianson, M.M, * Kurumeh, M.S and Obida, J.A. \\ Mathematics Unit, Department of Curriculum and Teaching, \\ Faculty of Education, Benue State University, Makurdi, Nigeria \\ searchhbk@yahoo.com, +2348036588272, \\ *Seraphinakurumeh@yahoo.com, +2348062676626, \\ audujosehobida@yahoo.com, +2348032890438.
}

\begin{abstract}
This study investigated the effect of cooperative learning method compared with the conventional learning method in order to find out the retention level of students' in circle geometry. The study was carried out on senior secondary II students in the three education zones (Zone A, Zone B and Zone C) in Benue State, Nigeria. The ability of students to grasp and memorize a mathematical concept or topic that was taught has become a basic problem in secondary schools. These problems may arise due to inappropriate teaching methods being used to explain these topics. Hence, this study adopted the cooperative learning strategy to teach 358 senior secondary two (SSII) students circle geometry, and see how well the learning method may effectively improve on students' ability to retain concepts in mathematics in comparison to the conventional learning method of teaching. An independent T-test analysis was used to determine whether a statistical significant difference existed between the cooperative learning approach and the conventional learning approach in terms of students' retention of the taught concept $\left(t_{(356)}=8.474, p=0.001\right)$. The findings of the study confirmed that students who were subjected to the cooperative learning strategy were able to retain the concepts of circle geometry more than those students who were taught using the conventional learning approach. Hence the recommendations were that, students would be able to retain taught and learnt concepts in mathematics for a longer period of time if mathematics teachers applied the cooperative learning strategy in teaching.
\end{abstract}

Keywords: Cooperative learning, Retention, Circle geometry, Mathematical concept, Teaching method, Conventional learning approach

\section{INTRODUCTION}

Many students turn out to be very miserable and inattentive in a mathematics class after being taught a topic and discover they could not memorize or recall such a concept with ease. The reason for this difficulty may vary but this could sometimes be related to the teaching method being used to explain such topics.Udeinya \& Okabiah (1991), blamed poor performance of students in mathematics on poor methods and approaches to teaching which has reduced the level of motivation. Harbor-Peters (2001) asserted that the issue of poor performance in mathematics examinations was due to problem of teaching methods. There has also been an increasing awareness by those concerned with mathematics education that the conventional methods of teaching mathematics, has not been very successful. For effective teaching to take place, the skillful mathematics teacher needs to use many different methods and techniques at his disposal. A carefully designed teaching method can make teaching and learning effective (Chianson in Kurumeh \& Opala, 2008). One of the many teaching methods proposed by Johnson \& Johnson, 1991; Slavin, 1990, that results in positive effect on students' achievement and retention of information is cooperative learning. Yi-wen (1999) defined cooperative learning as a kind of learning strategy in which students study together and complete common goals. Each student contributes his/her own efforts in small groups to promote all students' performance. In this process, students produce interaction to involve many activities such as communication, observation and support. Mckeachie (1999) explains that, in a cooperative learning class, students often elaborate on the concepts being taught to achieve what is expected. Elaboration provided from one student to another is a win/win situation. Elaboration not only 
enhances the learning of students who receive the explanation but also deepens the understanding of the student providing the explanation. Hence, consistent elaboration or explanation of a topic would surely bring forth complete retention of a topic being learnt for a longer period of time.

Retention is defined by Kundu \& Tutoo (2002) as a preservative factor of the mind. The mind acquires the materials of knowledge through sensation and perception. These acquired materials in the mind need to be preserved in form of images for knowledge to develop. Whenever a stimulating situation occurs, retained images are revived or reproduced to make memorization possible. Hence mathematics concepts need to be presented to the learners in a way or method that touches their subconsciousness which can trigger quick recalling of the concept being taught or learnt. Using such a teaching method as cooperative learning, both high ability and low ability learners would be able to collaborate in terms of understanding, explaining and retaining the concept they have learnt in a mathematics class.

Statement of Problem: Students express difficulty in understanding and retaining concepts being taught to them by their teachers. Researchers identified that how well students retain taught mathematics concept can be traced back to the teaching approach used.

How well can cooperative learning strategy influence students' ability in retaining mathematics concept being taught in secondary schools?

Purpose of the Study: The purpose of the study was to investigate the effect of the cooperative learning strategy in enhancing the retention of circle geometry concepts being taught to secondary school students.

Research Question: In the course of the study, the following research question was formulated:

1) What is the difference in the mean retention scores of students taught circle geometry using the cooperative learning strategy and those taught using the conventional approach?

Hypothesis: To achieve the objective of the study, the following null hypothesis was tested at a 0.05 level of significance:

1) There is no significant difference in the mean retention scores of students taught circle geometry using the cooperative learning strategy and those taught using conventional method.

Method and Procedures: The sample for the study was made up of $358 \mathrm{SSII}$ students randomly selected from three local government areas from the three education zones in Benue State. Purposive sampling was used to select six government co-educational schools for the study. Simple random sampling was used to select two intact classes from each of the six schools. They were assigned randomly to experimental and control group. The researcher picked two classes from each selected schools and assigned them to experimental and control group using the "hat and draw" method. 174 students were assigned to the cooperative learning group and 184 were assigned to the conventional learning group. The design adopted for the study was the quasiexperimental design. The study was conducted such that a Pre-GAT (Geometry Achievement Test) was administered, five weeks after circle geometry was taught to both group of students, Post-GAT was administered. Four weeks after the Post-GAT, the RET-GAT (Retention Geometry Achievement Test) was administered to the students. The RET-GAT was to test the student's retention level after the topic had been taught to them. The four weeks gap was allotted between the tests because the researcher assumed that after four weeks, the students may have forgotten the questions of the GAT. The GAT is a 20 items with 4-option multi choice test. A pilot study was carried out on a school not selected to participate in the study. This was to test for the reliability coefficient of the instrument being used. The scores obtained were subjected to the Cronbach-Alpha coefficient/method; the analysis yielded a 0.73 alpha coefficient of which this is considered as good internal consistency (Pallant, 2001).

The researcher organized a two day orientation programme for the research assistants who were the regular mathematics teachers of the selected schools. The teachers for the cooperative learning group were trained on how to teach the experimental group (cooperative learning group) and the teachers for the control group (conventional learning group) were also trained on how to conduct their lessons.

\section{RESULTS AND CONCLUSION}

The following results were obtained in the course of this research:

The result from Table 1 showed that the experimental group obtained a mean score of 22.3 and standard 
deviation of 13.5 in the Retention- Geometry Achievement Test. The control group obtained a mean score of 12.7 and a standard deviation of 7.7 in the retention test. This result indicated a mean difference of 9.6 in favour of those in the experimental group.

An independent t-test was carried out to compare the effect of the teaching methods on students' retention

Table 1:RET-GAT table showing student retention group statistics

\begin{tabular}{llcccc}
\hline Group & & $\mathrm{N}$ & Mean & Std.Dev & Std. Error Mean \\
\hline Retention & Experimental & 174 & 22.2701 & 13.4998 & 1.0234 \\
& Control & 184 & 12.6630 & 7.652 & 0.5282 \\
& Total & 358 & & & \\
\hline
\end{tabular}

Table 2:Table showing t-test for equality of means

\begin{tabular}{|c|c|c|c|c|c|c|c|c|}
\hline & & \multicolumn{3}{|c|}{$\begin{array}{l}\text { Levene's test for equality } \\
\text { of variance }\end{array}$} & \multicolumn{3}{|c|}{ t-test for equality of means } & \multirow[b]{2}{*}{$\begin{array}{c}\text { Std } \\
\text { error dif }\end{array}$} \\
\hline & & $\mathrm{F}$ & Sig & $\mathrm{t}$ & df & Sig(2-tailed) & $\begin{array}{c}\text { mean } \\
\text { dif }\end{array}$ & \\
\hline \multirow[t]{2}{*}{ RET } & $\begin{array}{l}\text { Equal Var. } \\
\text { Assumed }\end{array}$ & 65.015 & .001 & 8.474 & 356 & .001 & 9.6071 & 1.1338 \\
\hline & $\begin{array}{l}\text { Equal Var. } \\
\text { Not assumed }\end{array}$ & & & 8.342 & 260.007 & .001 & 9.6071 & 1.1517 \\
\hline
\end{tabular}

of circle geometry concept. The result in table 2 indicates that there was a significant difference in the student retention between the experimental and the control group $\left(\mathrm{t}_{(356)}=8.474, \mathrm{p}<0.05, \mathrm{r}=0.41\right)$. The $\mathrm{p}$ value is 0.001 and therefore, the difference between the two means is statistically significantly different at 0.05 level of significance. There is an estimated change of $9.6 \%$ (SE= 1.13\%).

Hence there is sufficient evidence $(p=0.001)$ to suggest that cooperative learning method has an effect on student retention on circle geometry concept.

Based on the findings of the research the following conclusions were drawn;

1. Cooperative learning approach can capture students' attention in class activity and give them the zeal to work tirelessly in a mathematics class.

2. Cooperative learning can enhance a better retention and recalling of circle geometry concept being taught to the students.

\section{DISCUSSION}

The result in table 2 indicated that students in the experimental group retained the circle geometry concept longer and could recall faster than those in the control group. This good performance is attributed to the application of the cooperative learning method. The result supported Anyagh (2006) who discovered that the ability to remember takes place more effectively when experiences are passed across to the learner via an appropriate instructional method. Table 2 showed a mean difference of 9.6 when comparing the means of the two groups. This difference could be attributed to the fact that students in the cooperative learning group were able to follow the guiding rules of working as a group. These rules are simply; explaining to group members what the content is all about. Making sure all group members are supportive of the group. Every member of the group has learnt, comprehended and is able to recall the concept learnt when the need arises. This result is in line with that of Nichols (2002), who agreed that students in the cooperative treatment group exhibited significantly greater gains in the post test and retention test in geometry achievement, efficacy, intrinsic valuing of geometry, learning goal orientation and reported uses of deep processing strategies.

Implications and Recommendations: Since cooperative learning was found to be more effective in the teaching of circle geometry in terms of retention, this implies that the students in the cooperative learning group maximized the rules binding on the successful implementation of cooperative learning. This also implies that group 
members elaborated on the concept taught such that the tendency of difficulty in recalling was suppressed.

Secondary school teachers are advised to adopt the cooperative learning approach and use it to teach students circle geometry for easier concept understanding and retention.

Workshops should be organized by educational bodies to emphasize and enlighten teachers and mathematics educators on the importance of the cooperative learning approach.

Additional research should be conducted in terms of retention of taught concepts when the cooperative learning approach is applied.

\section{REFERENCES}

Anyagh, I.P. (2006). Effect of Formula Approach on Students' Achievement and Retention in Algebra. Unpublished Master's Thesis. Benue State University.

Chianson, M.M (2008). Cooperative learning: in Kurumeh, M.S. \& Opala, M.F (eds) Innovative Teaching Approaches of Mathematics Education in the $21^{\text {st }}$ Century. Vol. 1, Pp: 27-40. Makurdi: Nigeria. Azaben Press.

Harbor Peters, V.F.A (2001) Unmasking Some Aversive Aspect of School Mathematics and Strategies for Averting them. Inaugural Lecture: 5 th, July.
Johnson, D.W. \& Johnson, R. (1991). Cooperation in the Classroom. Edina, Minnesota: Interaction Boob Company.

Kundu, C.L \& Tutoo, N.N (2002). Educational Psychology. Sterling Publishers: New Delhi.

Mckeachie, W. (1999). Teaching Tips: Strategies, Research and Theory of College and University Teachers. $\left(10^{\text {th }}\right.$ ed). Houghton Mifflin, Boston M.A, USA. P.16.

Nichols, J. D (2002). The Effects of Cooperative Learning on Students' achievement and Motivation in High School Geometry Class. (ERIC Document Reproduction Service NO ED 387341).

Pallant, J. (2001). SPSS Survival Manual: A Step by Step Guide to Data Analysis using SPSS for Windows (Versions 10 and 11) Bershire.UK: Open University Press.

Slavin, R.E (1990). Student Team Learning in Mathematics. In $\mathrm{N}$ Davidson (ed). Cooperative Learning in Mathematics:A Handbook for Teachers ( $p p$ 62-102) Menlo Park CA: Addison-Westley.

Udeinya, C.S \& Okabiah, O.S (1991): Special methods of Teaching Science Subjects Enugu: ABIC.

Yi-wen, C (1999). A Synthesis of Research on Cooperative Learning with Mathematics. Curriculum and Instruction 490. Final Paper. 